\title{
The effect of white scours on the sodium and potassium concentration in the serum of newborn calves
}

\author{
BY J. H. B. ROY, K. W. G. SHILLAM, GILLIAN M. HAWKINS \\ AND JILL M. LANG \\ National Institute for Research in Dairying, Shinfield, Reading \\ AND P. L. INGRAM \\ Department of Pathology, Royal Veterinary College, Camden Town, London, N.W. I \\ (Received 5 November 1958)
}

Calves that die from white scours associated with Escherichia coli infection show two distinct but related conditions at post-mortem examination (Wood, I955). Calves that die after being deprived of colostrum usually scour slightly, but with few exceptions show an $E$. coli septicaemia at post-mortem, whereas the majority of those that die after being given sufficient colostrum to protect against the septicaemic form of death scour profusely, become dehydrated and show a localized intestinal infection in which $E$. coli can be isolated only from the intestinal tract in very large numbers, and occasionally in small numbers from the mesenteric lymph nodes. The loss of body-weight is very pronounced but little information is available on the resultant change in electrolyte concentration in the blood.

To add to existing knowledge of the reasons for the death of these colostrum-fed calves, determinations of serum sodium and potassium have been made on $15^{2}$ calves that were used in experiments during the year $1955^{-6}$.

\section{METHODS}

\section{Calves}

The calves were in four different experiments, but none of the treatments affected the incidence of scouring. Of 150 calves, forty were deprived of colostrum, of which thirty were given various fractions of egg (Roy, Shillam \& Hawkins, I956), 100 received $400 \mathrm{ml}$ of separated colostrum and ten received 6 pints $(3410 \mathrm{ml})$ of whole colostrum.

The calves were given whole milk or a 'synthetic milk' based on spray-dried skim milk at the daily rate of $\mathrm{I} \mathrm{lb}$ milk/ Io lb live weight. At the onset of scouring, the milk intake was reduced to the quantity required for maintenance of body-weight (Roy, Shillam, Hawkins \& Lang, I958) until the faeces became of normal consistency, and the quantity was then increased to the full ration.

To verify that any changes in values for serum sodium and potassium were largely an effect of scouring rather than of a reduced milk intake, two calves, referred to in Table I, were each given $400 \mathrm{ml}$ separated colostrum followed by quantities of milk estimated to give maintenance of body-weight or I lb live-weight gain/day during alternate weeks of the 3 -week experimental period. 


\section{Serum determinations}

Blood samples were obtained from the jugular vein of the calves at birth before they suckled, on the Ist day of life and then on alternate days of life until they were 3 weeks of age; blood samples were allowed to clot at room temperature for about $30 \mathrm{~min}$ and were then stored at $4^{\circ}$ for $\mathrm{I}-\mathrm{I} \frac{1}{2} \mathrm{~h}$ before the serum was separated from the clot. Determinations of potassium in eight samples of blood collected at the same time from a $2 \mathrm{I}$-day-old calf showed that no demonstrable leakage of potassium from the red cells occurred during the first $2 \mathrm{~h}$ after collection of the blood. The values obtained were as follows:

$\begin{array}{cccc}\begin{array}{c}\text { Time after } \\ \text { collection }(\mathrm{h})\end{array} & \begin{array}{c}\text { Serum K } \\ \text { (m-equiv./1.) }\end{array} & \begin{array}{c}\text { Time after } \\ \text { collection }(\mathrm{h})\end{array} & \begin{array}{c}\text { Serum K } \\ \text { (m-equiv./1.) }\end{array} \\ \frac{1}{2} & 5^{\cdot 8} & 33^{\frac{1}{2}} & 6 \cdot \mathrm{I} \\ \mathrm{I} & 5^{\cdot 9} & 4 & 6 \cdot \mathrm{I} \\ \mathrm{I}^{\frac{1}{2}} & 5^{\circ} & 5 & 6 \cdot 4 \\ 2 & 5^{\cdot 9} & 6 & 6 \cdot 4\end{array}$

On three occasions blood samples were taken by heart puncture just before death. All serum samples showing signs of haemolysis were discarded.

Sodium and potassium determinations were made on the serum samples with an EEL (Evans Electroselenium Ltd) flame photometer.

\section{RESULTS}

The two calves given different quantities of milk during the first 3 weeks of life showed the mean daily values of serum sodium and potassium recorded in Table $\mathbf{r}$.

Table I. Mean values for serum sodium and potassium of two calves each given $400 \mathrm{ml}$ separated colostrum, and milk for maintenance or for a gain of $\mathrm{I} l b /$ day

\begin{tabular}{|c|c|c|c|}
\hline & \multicolumn{3}{|c|}{ Days } \\
\hline & $0-7$ & $8-14$ & $15-21$ \\
\hline \multicolumn{4}{|c|}{ Calf A } \\
\hline & $\begin{array}{c}\text { I lb gain/day } \\
\text { (7 pints milk/day) }\end{array}$ & $\begin{array}{c}\text { Maintenance } \\
\text { (4 pints milk/day) }\end{array}$ & $\begin{array}{c}\mathrm{x} \mathrm{lb} \text { gain/day } \\
(7 \text { pints milk/day) }\end{array}$ \\
\hline $\begin{array}{l}\text { Serum } \mathrm{K} \\
\text { (m-equiv./1.) }\end{array}$ & $6 \cdot 0$ & $6 \cdot 0$ & 5.9 \\
\hline Serum Na & $135 \cdot 1$ & I33.9 & 133.7 \\
\hline \multicolumn{4}{|c|}{ Calf B } \\
\hline & 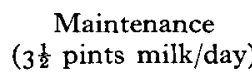 & $\begin{array}{c}\text { I lb gain/day } \\
\text { (7 pints milk/day) }\end{array}$ & $\begin{array}{c}\text { Maintenance } \\
\text { (4 pints milk/day) }\end{array}$ \\
\hline $\begin{array}{l}\text { Serum K } \\
\text { (m-equiv./1.) }\end{array}$ & $6 \cdot 0$ & $6 \cdot 6$ & $6 \cdot 0$ \\
\hline $\begin{array}{l}\text { Serum Na } \\
\text { (m-equiv./1.) }\end{array}$ & $13 \times 7$ & $128 \cdot 5$ & $\mathrm{I} 34^{\cdot} \mathrm{I}$ \\
\hline
\end{tabular}

From these values, it would appear that quite large changes in milk intake over a period of I week have little effect in the absence of scouring on serum-electrolyte values. The somewhat low mean value of serum sodium for calf $B$ from the 8 th to the I $4^{\text {th }}$ day was caused by unaccountably low values on the 8th and I ith days. 
Of the 150 calves in the four experiments, rog survived the experimental period of 3 weeks and were grouped according to their incidence of scouring as follows:

$\begin{array}{cc}\begin{array}{c}\text { No. of days on } \\ \text { which scouring } \\ \text { occurred }\end{array} & \begin{array}{c}\text { No. of } \\ \text { calves }\end{array} \\ 0-1 & 20 \\ 2-3 & 22 \\ 4-5 & 25 \\ 6-7 & 20 \\ >7 & 22\end{array}$

For each of these groups the mean values for serum sodium and potassium were calculated and are shown in Fig. I, together with histograms showing the percentage of the calves that scoured on each day.
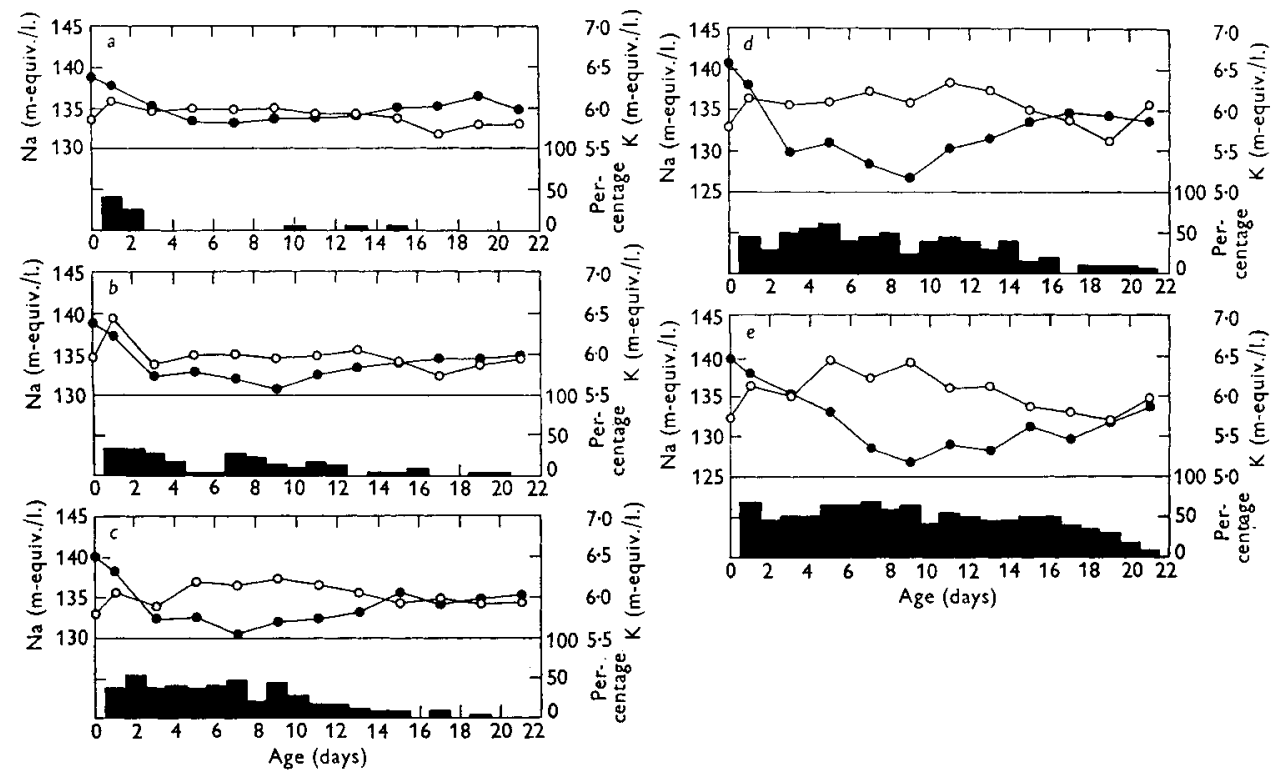

Fig. I. Mean values for serum sodium (-—) and potassium $(0-0)$ of calves that survived, and their relationship with incidence of scouring and age of calf. $a$, calves that did not scour or scoured on I day only; $b$, calves that scoured on 2 or 3 days; $c$, calves that scoured on 4 or 5 days; $d$, calves that scoured on 6 or 7 days; $e$, calves that scoured on 8 days or more. The shaded areas show the percentage of calves that scoured on any one day.

Mean serum-sodium values at birth were 139 -- $140 \mathrm{~m}$-equiv./1. for all groups of calves, and for those that did not scour or scoured only on $\mathrm{I}$ day the values fell to $133.5 \mathrm{~m}$-equiv./1. at the $5^{\text {th }}$ day and then gradually rose to $135^{\circ} 0 \mathrm{~m}$-equiv. $/ 1$. at the end of the 3 -week period (Fig. $1 a$ ). With increasing incidence of scouring, a greater fall in mean serum-sodium values occurred. When scouring occurred on 6 days or more (Fig. I $d$ and $e$ ) the lowest level was reached on the 9th day of life with mean values of $127^{\circ} \circ \mathrm{m}$-equiv./1. Thereafter the values rose nearly to normal by the end of the 3 -week period.

Mean serum-potassium levels at birth were 5.8-6.0 m-equiv./1. for all calves and rose on the Ist day of life to $6 \cdot I-6 \cdot 5 \mathrm{~m}$-equiv./1. For calves that scoured on $I$ day or 
not at all the mean serum potassium fell gradually to $5.8 \mathrm{~m}$-equiv./1. by the end of the experimental period. With increasing incidence of scouring, the potassium levels showed a slight increase during the 4 th- 12 th days of life with mean values reaching 6.5 m-equiv./1. for those calves scouring on more than 7 days.

Of the forty-one calves that died, twelve showed an $E$. coli septicaemia at postmortem, twenty-eight deaths were associated with localized intestinal infection with $E$. coli and the cause of the remaining death could not be ascertained.
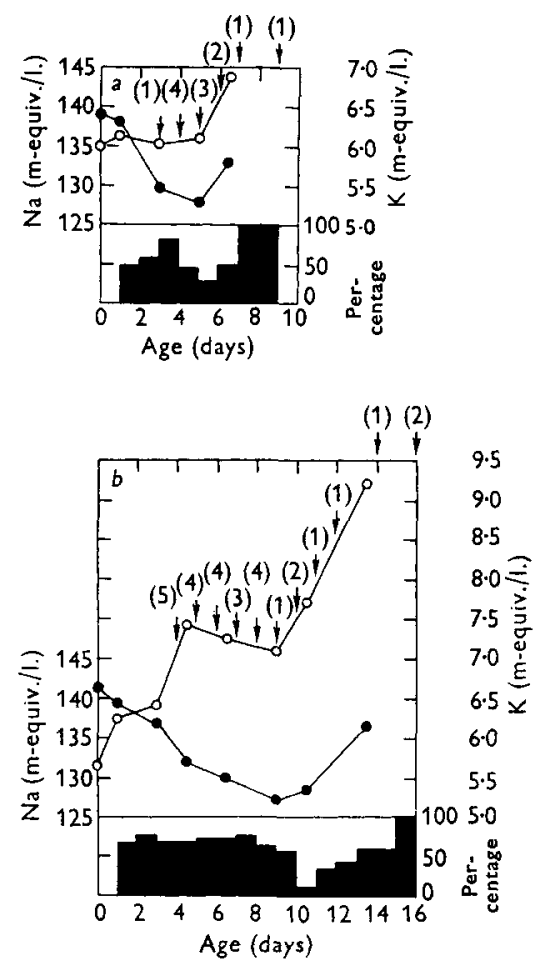

Fig. 2. Mean values for serum sodium (-—) and potassium ( $\left.\mathrm{O}-{ }_{-} \mathrm{O}\right)$ of calves that died $(a)$ from an $E$. coli septicaemia and (b) from a localized intestinal infection with $E$. coli. Figures in parentheses are the numbers of calves that died on each day. The shaded areas show the percentage of calves that scoured on any one day.

All deaths from an $E$. coli septicaemia, except one, were of calves that had been deprived of colostrum, whereas deaths associated with a localized intestinal infection were restricted to colostrum-fed calves, except for two that had been deprived of colostrum and had been given various fractions of egg.

The mean values for serum sodium and potassium for the forty calves that died from known causes are shown in Figs. 2 and 3 . The mean values from birth to death for calves showing the two different post-mortem findings, together with histograms showing the percentage of the calves that scoured on each day, are given in Fig. $2 a$ and $b$, and the mean values at various times during the last $\mathrm{I} 30 \mathrm{~h}$ of life in Fig. $3 a$ and $b$.

Calves that died from an $E$. coli septicaemia showed a fall in serum sodium to 
I27.0 m-equiv./1. at death, with a slight rise in serum potassium from $6.0 \mathrm{~m}$-equiv./1. at $52 \mathrm{~h}$ before death to 6.7 at $9 \mathrm{~h}$ before. As can be seen from Fig. $2 a$, most of the deaths occurred when the sodium level was low and the potassium level normal.

Calves whose deaths were associated with a localized intestinal infection with $E$. coli showed a fall in serum sodium similar to that of those calves that survived after profuse scouring and to that of those calves that died from an E. coli septicaemia. However, the serum-potassium levels of the calves that subsequently showed a localized intestinal infection increased steadily from birth until death when mean values greater than
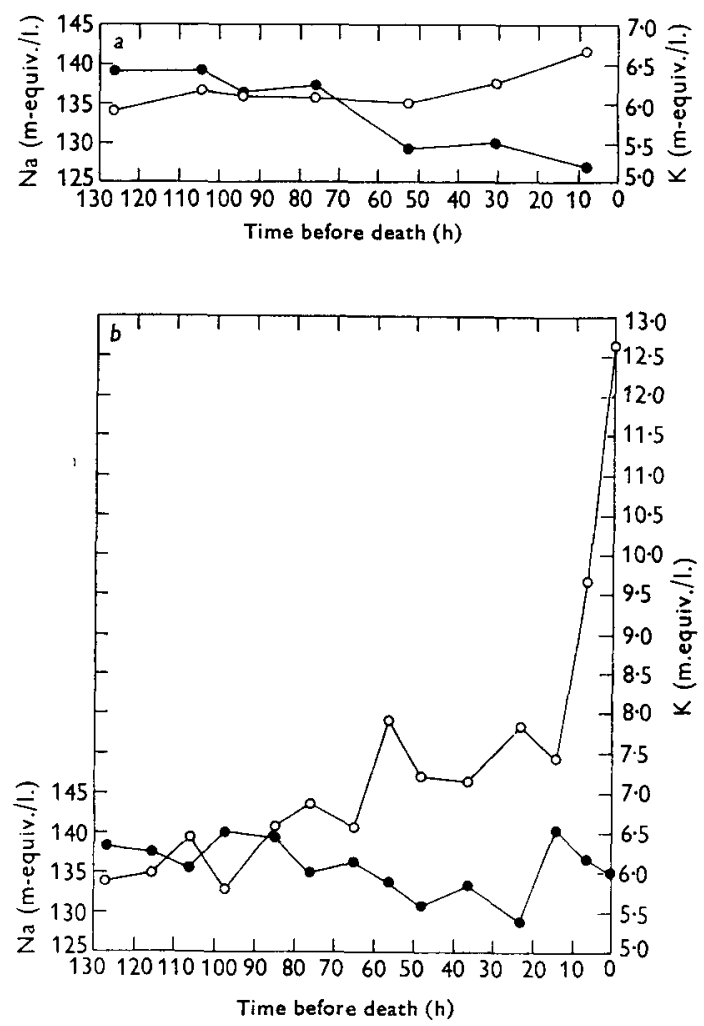

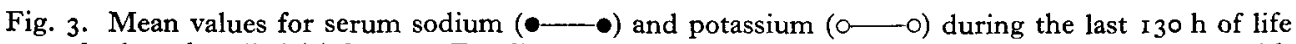
of calves that died $(a)$ from an $E$. coli septicaemia and $(b)$ from a localized intestinal infection with E. coli.

7.I m-equiv./1. were obtained. As can be seen from Fig. $3 b$, mean values from $9 \cdot 5$ to I $2.5 \mathrm{~m}$-equiv./1. were obtained during the last Io $\mathrm{h}$ before death but, since two of the three values in this period were obtained by heart puncture and since Hoffman (I950) points out that serum potassium concentration rises in agonal states, the values may not be strictly valid for reasons other than those associated with dehydration. It is also possible that, between the time of collection of the blood and centrifugation, some leakage of potassium from the red cells into the serum may have occurred with calves that were dehydrated and thus had a large packed-cell volume. Moreover, 
although no leakage of potassium from the red cells into the serum occurred during the first $2 \mathrm{~h}$ after collection in samples from a 21 -day-old calf, it must be borne in mind that the fragility of the erythrocytes decreases gradually from birth (Holman, 1956).

\section{DISCUSSION}

The results of this study show clearly that, with an increased incidence of scouring, the serum-sodium levels of calves decline with a concomitant but slight rise in potassium values. For calves whose deaths are associated with a localized intestinal infection with $E$. coli, serum-potassium values rise until death occurs, whereas those that die from an $E$. coli septicaemia show values similar to those of calves that scour badly but nevertheless survive.

The overall electrolyte distribution in the serum of the young calf was not studied in this experiment, but certain conclusions are possible from our determinations of the main basic constituents. Blaxter \& Wood (I953) showed that about eighteen times more water and eleven times more sodium and potassium were lost each day in the faeces of scouring calves than in those of normal calves. They suggested that this loss was due to the increasing osmotic pressure in the lumen of the gut owing to an increase in the number of smaller molecules, such as volatile fatty acids, resulting from bacterial activity. The higher osmotic pressure in the gut thus caused the infiltration of large amounts of water accompanied by electrolytes.

McSherry \& Grinyer (1954 $b$ ) studied the serum electrolytes in eighteen calves with diarrhoea and compared the values with those for twenty normal calves aged 4 days to Io weeks (McSherry \& Grinyer, I954a). They stored their blood samples after collection for $2 \mathrm{~h}$ at room temperature before centrifugation. Their normal values were $\mathrm{I}_{42} \cdot \mathrm{I}$ and $5.3 \mathrm{~m}$-equiv./1. for sodium and potassium, respectively, which differ from the values of about $\mathrm{I} 35$ and $5.9 \mathrm{~m}$-equiv./l. obtained by us during the first 3 weeks of the life of calves that had scoured on I day or not at all during the period. As there are indications from our results that serum sodium increases gradually with age with a concomitant decrease in serum potassium, it is questionable whether the values of McSherry \& Grinyer for normal calves can be used as standards for the first 3 weeks of life. Of their eighteen calves twelve were in the age period of our experiment, but only one (no. I I) appeared to show the low sodium and high potassium values found by us to be associated with an incipient localized intestinal infection with $E$. coli.

The changes that may lead to an increase in the concentration of potassium in the serum of the young calf deserve further discussion, for it seems possible that a high blood-potassium level may be the actual cause of death in calves with a localized intestinal infection with $E$. coli. Whereas Briggs, Lovell, Aschaffenburg, Bartlett, Kon, Roy, Thompson \& Walker (195I) demonstrated that the death of calves showing an $E$. coli septicaemia at post-mortem was undoubtedly a direct result of the presence of $E$. coli in the body tissues $36-48 \mathrm{~h}$ before death, the reason for the death of calves in which $E$. coli is localized in the small intestine is not clear (Wood, 1955). Bergman \& Sellers (1953) injected potassium chloride intravenously into calves weighing $48-$ $24 \mathrm{olb}$ and found severe signs when plasma-potassium levels reached about $8 \mathrm{~m}$ - 
equiv./1. and that one calf died from heart failure when a value of $12.7 \mathrm{~m}$-equiv./1. was reached. In a further report, Bergman \& Sellers (1954) showed that at high potassium levels heart rate became progressively slower and respiration rate increased in rate and amplitude. Gradual cardiac arrest, which appeared to be uniformly produced throughout the ventricles, was noted after plasma-potassium levels of $8 \mathrm{~m}$-equiv./1. had been attained.

Hoffman (1950) has reviewed the factors tending to increase serum-potassium concentration, namely increased potassium intake, loss of tissue substance, anoxia, contraction of the extracellular volume by dehydration, oliguria or anuria, and adrenal cortical deficiency. Of these factors, the first did not apply since milk intake, and thus potassium intake and presumably absorption, were reduced when calves scoured in our experiments. A reduction in the extracellular volume and loss of nitrogen from the tissues were certainly occurring, for calves dying from a localized intestinal infection lost up to $20 \%$ of their body-weight, and it is known that scouring calves are in negative nitrogen balance (Blaxter \& Wood, I953) and that, for every $g$ of nitrogen lost from the tissues $2.4 \mathrm{~g}$ of potassium would be released (Hoffman, 1950). As the serum potassium rose to abnormally high levels, failure of the kidneys to eliminate the excess potassium must also have occurred in the existing dehydration. Moreover, it is possible that there are functional changes in the adrenal cortex, for one of us (P.L.I.) has some evidence that the adrenals are enlarged in calves dying from localized intestinal infection with $E$. coli after profuse scouring, and Hawkins, Roy, Shillam, Greatorex \& Ingram (1957) have shown that the weight of the adrenals in calves at $2 \mathbf{I}$ days of age is positively related to the incidence of scouring during the preceding 3 weeks.

The high serum-potassium values obtained by us were no doubt the result of the release of cellular potassium combined with a reduction of the extracellular fluid and were, in fact, associated with an overall deficiency of potassium and sodium in the body as found by Blaxter \& Wood (1953). It is well known that an increase in potassium concentration in the serum can occur with a cellular deficiency of potassium (Hoffman, 1950), and Schlesinger, Payne \& Black (1955) have emphasized that potassium should never be given to dehydrated patients because of the danger of an increase in potassium concentration in the serum and cardiac arrest. The relative importance of the various factors leading to high serum-potassium concentrations in the young calf cannot at present be assessed, nor as yet is there any firm evidence that the high values for serum potassium obtained before death were alone responsible for the death of the calves that showed a localized intestinal infection with $E$. coli at post-mortem.

\section{SUMMARY}

I. Sodium and potassium determinations were made on the serum of $15^{2}$ calves during the first 3 weeks of life.

2. Forty calves were deprived of colostrum, 102 received $400 \mathrm{ml}$ and ten were given 6 pints (34 $\mathrm{ro} \mathrm{ml}$ ) colostrum. All were reared on whole milk or on a 'synthetic milk', based on dried skim milk, at the rate of $\mathrm{I} \mathrm{lb}$ milk/ı $\mathrm{lb}$ live weight. 
3. One hundred and eleven calves survived the experimental period. With increasing incidence of scouring, the fall in serum-sodium values after birth became greater with a concomitant but slight rise in potassium values.

4. Forty-one calves died, of which twelve showed at post-mortem an Escherichia coli septicaemia and twenty-eight a localized intestinal infection with $E$. coli. The values for serum sodium and potassium of those calves that died from an $E$. coli septicaemia were similar to those of calves that scoured but recovered.

5. The serum-sodium values of calves whose deaths were associated with a localized intestinal infection with $E$. coli were similar to those of the calves that died from an $E$. coli septicaemia, but the serum-potassium values of the former calves increased after birth until death occurred.

6. The possibility is discussed that calves, whose deaths are associated with a localized intestinal infection with $E$. coli, may succumb to cardiac arrest as a result of the high concentration of potassium in the serum.

We thank Dr J. A. F. Rook for his advice, and Dr R. Aschaffenburg, Dr S. Bartlett and Dr S. K. Kon of the National Institute for Research in Dairying and Professor R. Lovell of the Royal Veterinary College for their interest in the work.

\section{REFERENCES}

Bergman, E. N. \& Sellers, A. F. (1953). Amer. F. vet. Res. 14, 520.

Bergman, E. N. \& Sellers, A. F. (1954). Amer. F. vet. Res. 15, 25.

Blaxter, K. L. \& Wood, W. A. (1953). Vet. Rec. 65, 889.

Briggs, C., Lovell, R., Aschaffenburg, R., Bartlett, S., Kon, S. K., Roy, J. H. B., Thompson, S. Y. \& Walker, D. M. (195r). Brit. F. Nutr. 5, 356.

Hawkins, G. M., Roy, J. H. B., Shillam, K. W. G., Greatorex, J. C. \& Ingram, P. L. (1957). Unpublished work.

Hoffman, W. S. (1950). F. Amer. med. Ass. r44, I I 57.

Holman, H. H. (1956), Brit. vet. F. 112, 91.

McSherry, B. J. \& Grinyer, I. (1954a). Amer. F. vet. Res. 15, 509.

McSherry, B. J. \& Grinyer, I. (1954b). Amer. F. vet. Res. 15, 535.

Roy, J. H. B., Shillam, K. W. G. \& Hawkins, G. M. (1956). Rep. nat. Inst. Dairy., Reading, p. 5 I.

Roy, J. H. B., Shillam, K. W. G., Hawkins, G. M. \& Lang, J. M. (I958). Brit. F. Nutr. 12, I23.

Schlesinger, B., Payne, W. \& Black, J. (1955). Quart. F. Med. 24, 33.

Wood, P. C. (1955). F. Path. Bact. 70, 179. 